\title{
The Practices of Teaching Listening Skill in EFL Classes: General Tadesse Biru Secondary School Grade Nine (9) English Language Teachers in Focus
}

\author{
Ebissa Bekele Abate, $\mathrm{PhD}^{1} \quad$ Abdeta Emiru Dukan ${ }^{2}$ \\ Assistant Professor, Department of English Language and Literature, Wollega University, Nekemte, Ethiopia \\ MA student, Wollega University, Department of English Language and Literature, Nekemte, Ethiopia
}

\begin{abstract}
As to the researcher's subjective experience and observations, the teaching of listening skill in government secondary schools in Ethiopian pedagogic context seems to be neglected. For instance, it seems that English language teachers do not seriously teach this skill as compared to the other language skills. Therefore, the objective of this study was to investigate the practice of teaching listening skill in secondary schools with specific reference to General Tadese Biru Secondary School Grade 9 English language teachers. To this effect, the researcher focused on the actual practice of English language teachers in teaching listening skill in terms of employing listening strategies and sub listening skills, the extent to which English language teachers use the three stages of listening skill, and the English language teachers' use of appropriate listening materials. Descriptive case study design involving both qualitative and quantitative research approaches was employed. Three English language teachers were selected through availability sampling technique and 78 students were selected using simple random sampling technique. Three data gathering tools: questionnaire for students, classroom observations and interview for English language teachers were used. To ensure the validity and reliability of the tools, a pilot study was conducted in selected secondary schools. The data obtained through questionnaire and classroom observations were analyzed quantitatively and qualitatively, whereas; the data obtained through interview were analyzed qualitatively. The findings of the study revealed that the English language teachers failed to employ perceptive strategies, cognitive strategies and meta-cognitive strategies well in teaching listening skill, and did not make student practice well the sub listening skills; the English language teachers employed the while listening stage to some extent, but they used the pre listening stage and the post listening stage to some extent; the English language teachers failed to use appropriate listening materials- both printed and electronic. Based on the findings, pertinent recommendations were suggested to the concerned stakeholders.
\end{abstract}

DOI: $10.7176 / \mathrm{JCSD} / 62-04$

Publication date:October $31^{\text {st }} 2020$

\section{INTRODUCTION}

It is a commonly accepted truth that language plays important roles in human life. That is, it is through language that people express their ideas, feelings, happiness, sorrow and much more. Regarding this, Naved (2015) asserts that language is the primary means of communication and an instrument through which human beings share their ideas and thoughts with others. Yet, learning universal language has more vitality than learning other languages as it is widely used in communication (Harmer, 1991). Similarly, Naved (2015) adds that English as an international language is essential because it is the dominant language in science and the language in which most researches are written. These ideas show that learning international language in general and English language in particular has a significant importance to converse globally.

Being able to well communicate in English, on the other hand, emanates from mastering the four skills of the language: listening, speaking, reading and writing in which listening skill is the first skill human being experiences and the most widely used skill in the process of language learning. With regard to this, Bililew and Girma (2015) state that listening skill is not only the first language skill developed, but also the skill most frequently used both in the classrooms and in a daily life. As to the scholars, adults spend about $40-50 \%$ of communication time listening, $25-30 \%$ speaking, $11-16 \%$ reading, and $9 \%$ writing. The large percentage (40-50\%) use of listening over the other skills witnesses that listening skill is the most frequent skill used in people's life in general and in EFL classroom in particular. Further, Wolvin and Coackly (1996) state that till junior level listening is the most efficient learning mode, and $58 \%$ of elementary students' classroom time is spent listening and then, they move to other modes which heavily depends on listening skills.

In Ethiopian secondary schools too, where the medium of instruction is English, listening is one of the most vital ways through which students learn in classrooms. That is, it is through listening that students learn from their teachers' lectures, classroom presentations, discussions etc. This reveals that listening skill plays an important role in students' learning in Ethiopian secondary schools. Despite this, the teaching of listening skill seems to be ignored in government secondary schools in Ethiopia as far as the researcher's experience is concerned. In line with this, the objective of this study was to investigate the practice of teaching listening skill in EFL classes with 
reference to General Tadese Biru Secondary School Grade 9 English language teachers in focus.

\section{OBJECTIVES OF THE STUDY}

The general objective of this research was to probe the practice of teaching listening skill in EFL classes: General Tadese Biru Secondary School Grade 9 English language teachers in focus. Based up on the general objective, this research was intended to achieve the following specific objectives:

1. To examine English language teachers' practice of listening strategies and sub listening skills

2. To study the extent to which English language teachers' use the three stages of listening skill

3. To explore English language teachers', use of appropriate (authentic) listening materials

\section{RESEARCH DESIGN}

Descriptive case study design was used to gain detail insight on how English language teachers teach listening skill in EFL classes with reference to General Tadese Biru Secondary School Grade 9 in focus. In line with this, Nunan, (1992) states that descriptive case study is an intensive, holistic description and analysis of a single entity, phenomenon, or social unit. This scholar explains that descriptive case design is particularistic and heuristic and relies heavily on inductive reasoning in handling multiple data sources. Cohen et al. (2005) add that in descriptive case study, a researcher typically observes the characteristics of an individual unit- a child, a clique, a class, a school or a community. The scholars enunciated that the purpose of such observation is to probe deeply and to analyze intensively the multifarious phenomena that constitute the life cycle of the unit with a view to establish generalizations about the wider population to which that unit belongs. So, the researcher used descriptive case design to probe the way English language teachers teach listening skill in EFL classes with reference to General Tadese Biru Secondary School grade 9 English language teachers and to gain in-depth understanding on the issue under study so as establish inductive conclusions to the findings. To this end, the researcher used mixed research approach involving both qualitative and quantitative methods. According to Creswell (2014), mixed research approach is useful when the quantitative or qualitative method, each by itself, is inadequate to best understand a research problem and the strength of both quantitative and qualitative research can provide best understanding. Creswell (2014) extends that the core assumption of this form of inquiry is that a combination of both provides a more complete understanding of a research problem than either approach alone. Therefore, it was from this assumption that the researcher used mixed research approach to gather and analyze the data obtained through multiple instruments in the current study.

\subsection{SAMPLES AND SAMPLING TECHNIQUES}

The populations of the study were all the three (3) Grade nine (9) ELT teachers, and 390 grade nine (9) students of General Tadese Biru Secondary School in Addis Ababa city administration in 2019 G.C.

The researcher selected all the three Grade 9 English teachers of the School, all of which were male, using availability sampling. But the researcher used SRS for the sampled students. This particular technique was used to give equal chance of inclusion for the subjects. As far as the sample size for students is concerned, Cohen et al. (2005) state that there is no clear-cut answer to determine how large a sample size for a research should be for the correct sample size depends on the purpose of the study and the nature of the population. These scholars go on to explain that sample size might also be determined by cost- in terms of time, money, stress, administrative support, the number of researchers and resources. So, taking these into consideration, the researcher took $20 \%$ of the population as a sample of the study. Accordingly, 78 students (44 males and 34 females) were selected using random sampling technique from the total population of the students.

\subsection{INSTRUMENTS OF DATA COLLECTION}

To attain the research objectives, three instruments of data collection: questionnaire, classroom observation and interview were used to triangulate the data obtained from the respective respondents.

\subsubsection{QUESTIONNAIRE}

39 closed ended and 1 open ended item was used to collect data from the students. The reason for using open ended questionnaire was to make the students respond freely when necessary. The questionnaire was intended to answer research question number 1, 2, 3 and 4. It contained five-point Likert scale ranging from 'strongly agree' to 'strongly disagree' and rating scale ranging from 'very high' to 'very low'. To maintain reliability of the instrument, the researcher used classroom observation and interview to measure the same thing so that it was triangulated. Regarding this, Black (1999) asserts that reliability is an indication of consistency between two measures of the same thing. David et al. (2005) also add that to maintain reliability, the researcher should make certain that the participants understand the instruction and content of the instrument. They insist that if participants have difficulty understanding the purpose of the measure, they might not respond accurately, which has the potential to bias the data. Taking this into consideration, the researcher translated the questionnaire from the target language to the students' L1 (Afan Oromo). The researcher also explained the purpose of the instrument to the 
subjects to avoid suspicion to their privacy. To ensure the validity of the questionnaire, the researcher triangulated the data obtained via other instrument. Regarding this, Creswell and Miller (2005) state that to abate bias in qualitative research, it needs triangulation. Lastly, the researcher analyzed, interpreted and discussed the data obtained via students' questionnaire in a mixed style.

\subsubsection{CLASSROOM OBSERVATION}

The researcher used observation as a main data gathering tool as it is the tool in which live information can be gathered. He used classroom observation checklist adapted from Mekasha (2012) and Andres and Yasid (2016) to observe how English language teachers teach listening skill. The researcher used overt type of observation. The observation was intended to answer research question number 2, 3 and 4. Before the observation, the researcher informed all the concerned not only to keep the ethicality of the research, but also to create good rapport and to get support from the same. Accordingly, the researcher observed listening sessions of 3 teachers, 3 times each, which constitute a total of 9 sessions, and during the observation, he made a tick mark based on the checklist. To maintain reliability and validity of the tool, the researcher conducted a pilot study on similar subjects. Regarding this, Cohen et al. (2005) claim that a pilot study can be conducted to ensure that the observational categories themselves are appropriate, exhaustive, discrete, unambiguous, and effectively operationalize the purpose of the research. In addition, the researcher also triangulated the data sources to maintain reliability and validity of the tool.

\subsubsection{INTERVIEW}

The researcher prepared 6 semi-structured interview schedules for the 3 ELT teachers to collect pertinent data. Interview was chosen for the subjects were few, and it was believed that it would help him to obtain views and opinions of the respondents and other unexpected idea about issues under study that might not be obtained through other tools. Accordingly, the researcher prepared the interview questions based on the review of related literature. The interview was made to answer research question 1,2,3 and 4. Before the interview, the researcher got the respondents consent and discussed on interview setting. Likewise, the researcher informed them the purpose of the interview and that their genuine help would be valued. Hence, based on their willingness, the interview was conducted in the naturalistic context. The researcher interviewed the subjects in English and also took notes of their responses. The researcher deliberately made the interview after the classroom observations on the suspicion that the English language teachers would have made their ways of teaching listening artificial if he had interviewed them before the classroom observation. To ensure validity and reliability of the interview, the researcher triangulated the data obtained through questionnaire and classroom observation. Moreover, the researcher set semistructured interview based on the research questions and objectives of the study. In relation to this, Gray (2004) asserts that in case of structured and semi structured interviews, the issue of validity can be addressed by attempting to ensure that the questions contents directly cross ponds with research objectives. Finally, the researcher analyzed the data obtained through interview qualitatively.

\subsection{METHOD OF DATA ANALYSIS}

In this study, a mixed method of data analysis was used. First of all, the researcher collected and analyzed the data obtained from students' questionnaire both in qualitative and quantitative form. Second, the researcher gathered and analyzed the data obtained via classroom observation qualitatively and quantitatively. Third, he analyzed, discussed and interpreted the data gathered through respondent interview qualitatively. In concise statement, mixed method of data analyses was used.

\section{DATA ANALYSIS AND INTERPRETATION \\ 4.1. ANALYSIS AND INTERPRETATIONS OF QUESTIONNAIRE DATA}

In this part, analysis and interpretation of data obtained via students' questionnaire on the practice of ELT teachers in using listening strategies and sub listening skills, the extent to which the teachers teach listening using the 3 stages of listening skill and their experience of using suitable listening materials are presented. 
Table 4. 1.1: Students' responses to the actual practice of English language teachers in terms of using listening strategies and sub listening skills. Key: $S A=$ Strongly agree, A=Agree, U=Undecided, D= Disagree, $S D=$ Strongly disagree, $F=$ Frequency

\begin{tabular}{|c|c|c|c|c|c|c|c|c|}
\hline \multirow[t]{3}{*}{ No } & Items & & \multirow[t]{2}{*}{ SA } & \multirow[t]{2}{*}{ A } & \multirow[t]{2}{*}{$\mathbf{U}$} & \multirow[t]{2}{*}{ D } & \multirow[t]{2}{*}{ SD } & \multirow[t]{2}{*}{ Total } \\
\hline & \multicolumn{2}{|l|}{ Perceptive strategies } & & & & & & \\
\hline & $\begin{array}{l}\text { In a classroom, your English language teacher } \\
\text { practices teaching listening skill by: }\end{array}$ & & & & & & & \\
\hline \multirow[t]{2}{*}{1} & \multirow{2}{*}{$\begin{array}{l}\text { Helping you understand the speaker's use of } \\
\text { connected speech like 'nexday' to mean 'next } \\
\text { day' and 'gimme' to mean 'give me'. }\end{array}$} & $\mathrm{F}$ & - & 4 & 8 & 28 & 38 & 78 \\
\hline & & $\%$ & - & 5.1 & 10.3 & 35.9 & 48.7 & 100 \\
\hline \multirow[t]{3}{*}{2} & \multirow{2}{*}{$\begin{array}{l}\text { Helping you understand key terms before } \\
\text { listening. }\end{array}$} & $\mathrm{F}$ & 6 & 10 & 5 & 21 & 36 & 78 \\
\hline & & $\%$ & 7.7 & 12.8 & 6.4 & 26.9 & 46.2 & 100 \\
\hline & \multicolumn{2}{|l|}{ Cognitive strategies } & & & & & & \\
\hline \multirow[t]{2}{*}{3} & \multirow{2}{*}{$\begin{array}{l}\text { Encouraging you to relate what has been said to } \\
\text { your prior knowledge. }\end{array}$} & $\mathrm{F}$ & 4 & 6 & 8 & 29 & 31 & 78 \\
\hline & & $\%$ & 5.1 & 7.7 & 10.3 & 37.2 & 39.7 & 100 \\
\hline \multirow[t]{3}{*}{4} & \multirow{2}{*}{$\begin{array}{l}\text { Helping you to understand meanings that are } \\
\text { not directly stated. }\end{array}$} & $\mathrm{F}$ & 3 & 6 & 11 & 22 & 36 & 78 \\
\hline & & $\%$ & 3.8 & 7.7 & 14.1 & 28.2 & 46.2 & 100 \\
\hline & \multicolumn{2}{|l|}{ Metacognitive strategies } & & & & & & \\
\hline \multirow[t]{2}{*}{5} & \multirow{2}{*}{$\begin{array}{l}\text { Providing you with topic related tasks before } \\
\text { listening. }\end{array}$} & $\mathrm{F}$ & 3 & 5 & 8 & 27 & 35 & 78 \\
\hline & & $\%$ & 3.8 & 6.4 & 10.3 & 34.6 & 44.9 & 100 \\
\hline \multirow[t]{3}{*}{6} & \multirow{2}{*}{$\begin{array}{l}\text { Helping you rehearse pronunciation of topic } \\
\text { related vocabularies before listening. }\end{array}$} & $\mathrm{F}$ & 3 & 5 & 8 & 28 & 34 & 78 \\
\hline & & $\%$ & 3.8 & 6.4 & 10.3 & 35.9 & 43.6 & 100 \\
\hline & \multicolumn{2}{|l|}{ Socio affective strategies } & & & & & & \\
\hline \multirow[t]{2}{*}{7} & \multirow[t]{2}{*}{ Helping you to ask for clarification. } & $\mathrm{F}$ & 26 & 22 & 12 & 10 & 8 & 78 \\
\hline & & $\%$ & 33.3 & 28.2 & 15.4 & 12.8 & 10.3 & 100 \\
\hline \multirow[t]{2}{*}{8} & \multirow[t]{2}{*}{ Encouraging you to lower anxiety. } & $\mathrm{F}$ & 30 & 25 & 7 & 11 & 5 & 78 \\
\hline & & $\%$ & 38.5 & 32.1 & 8.9 & 14.1 & 6.4 & 100 \\
\hline 9 & Encouraging you to listen to the text despite & $\mathrm{F}$ & 34 & 28 & 5 & 7 & 4 & 78 \\
\hline & difficulties. & $\%$ & 43.6 & 35.9 & 6.4 & 9 & 5.1 & 100 \\
\hline & Sub listening skills & & & & & & & \\
\hline 10 & Encouraging you to predict what a text may be & $\mathrm{F}$ & 2 & 4 & 8 & 28 & 36 & 78 \\
\hline & & $\%$ & 2.6 & 5.1 & 10.3 & 35.9 & 46.1 & 100 \\
\hline 11 & Telling you not to worry to understand the & $\mathrm{F}$ & - & 6 & 10 & 29 & 33 & 78 \\
\hline & meanıng of every word you hear. & $\%$ & - & 7.7 & 12.8 & 37.2 & 42.3 & 100 \\
\hline 12 & Encouraging you to get the main idea of the text & $\mathrm{F}$ & 10 & 12 & 9 & 22 & 25 & 78 \\
\hline & & $\%$ & 12.8 & 15.4 & 11.5 & 28.2 & 32.1 & 100 \\
\hline 13 & Helping you to get the general understanding of & $\mathrm{F}$ & 8 & 11 & 6 & 26 & 27 & 78 \\
\hline & & $\%$ & 10.3 & 14.1 & 7.7 & 33.3 & 34.6 & 100 \\
\hline 14 & Making you practice listening for specific & $\mathrm{F}$ & 9 & 12 & 13 & 18 & 26 & 78 \\
\hline & & $\%$ & 11.5 & 15.4 & 16.7 & 23.1 & 33.3 & 100 \\
\hline
\end{tabular}

In Table 4.1.1, above items 1 and 2, 3 and 4, 5 and 6, and 7- 9 represent perceptive strategies, cognitive strategies, metacognitive strategies and socio affective strategies respectively, while item 10-14 represent sub 
listening skills (Harmer, 1991) and (Jarvis et al. 2018). Accordingly, the table shows that none (0\%) of the respondents 'strongly agree', $4(5.1 \%)$ of the respondents 'agree' and $8(10.3 \%)$ of the respondents opted for 'undecided', but $28(35.9 \%)$ and $38(48.7 \%)$ of the respondents confirmed that they 'disagree' and 'strongly disagree' respectively regarding item number 1 . Likewise, in item number $2,6(7.7 \%), 10(12.8 \%), 5(6.4 \%)$ of the respondents responded that they 'strongly agree', 'agree' and 'undecided' respectively, while $21(26.9 \%)$ and $36(46.2 \%)$ of the respondents responded that they 'disagree' and 'strongly disagree' respectively. As it can be seen from the above data, most of the respondents disagreed (35.9\%) and strongly disagreed (48.7) that their English language teachers helped them to understand the speaker's use of connected speech in listening classes. The data also show that most of the respondents disagreed (26.9\%) and strongly disagreed (46.2\%) that their English language teachers helped them to understand key terms before listening. In the classroom observations, too, the researcher did not observe English language teachers helping students to understand speaker's use of connected speech and it was only in session one, out of nine sessions, that he observed them helping students understand key terms before listening. These show that the English language teachers did not well employ perceptive strategies.

Likewise, in item number $3,4(5.1 \%), 6(7.7 \%)$ and $8(10.3 \%)$ of the respondents replied that they 'strongly agree', 'agree' and 'undecided' respectively, but 29(37.2\%) and 31(39.7\%) of the respondents responded that they 'disagree' and 'strongly disagree' respectively with the idea that 'the English language teachers encouraged the students to relate what has been said to their prior knowledge'. Similarly, in item number 4, 3(3.8\%), 6(7.7\%), and $11(14.1 \%)$ of the respondents responded that they 'strongly agree', 'agree' and 'undecided' respectively, whereas $22(28.2 \%)$ and $36(46.2 \%)$ responded that they 'disagree' and 'strongly disagree' respectively. These data show that most of the respondents disagreed (37.2\%) and strongly disagreed (39.7\%) that their English language teachers encouraged them to relate what had been said to their prior knowledge. Similarly, the data show that most of the respondent disagreed $(37.2 \%)$ and strongly disagreed (39.7\%) with the idea that their English language teachers helped them to understand meanings that were not directly stated in listening texts. Similarly, $88.9 \%$ and $100 \%$ of the observed classroom respectively witnessed that the English language teachers did not carry out the above points. Thus, these reveal that English language teachers did not well employ cognitive strategies in listening classroom.

In item $5,3(3.8 \%), 5(6.4 \%)$ and $8(10.3 \%)$ of the respondents replied that they 'strongly agree', 'agree' and 'undecided' respectively, but $27(34.6 \%)$ and $35(44.9)$ of the respondents responded that they 'disagree' and 'strongly disagree' respectively with regard to the idea that 'the English language teachers provided the students with topic related tasks before listening'. Similarly, in item number $6,(7.7 \%), 9(11.5 \%)$ and $8(10.3 \%)$ of the respondents responded that they 'strongly agree', 'agree' and 'undecided', while $25(32 \%)$ and $30(38.5 \%)$ responded that they 'disagree' and 'strongly disagree' respectively with regard to the idea that 'the English language teachers helped the students rehearse pronunciation of topic related vocabulary before listening'. The data show that most of the respondents disagreed (34.6\%) and strongly disagreed (44.9\%) that their English language teachers provided them with topic related tasks before listening. Similarly, the data depict that most of the respondents disagreed 25(32\%) and strongly disagreed 25(32\%) that their English language teachers helped them rehearse pronunciation of topic related vocabulary before listening. These have also been confirmed by classroom observations in that the researcher did not see English language teachers provide students with topic related tasks before listening and help students rehearse pronunciation of topic related vocabulary. Hence, the data show that English language teachers did not properly employ metacognitive strategies in listening sessions.

In item number $7,26(33.3 \%), 22(28.2 \%)$ and $12(15.4 \%)$ of the respondents responded that they 'strongly agree', 'agree' and 'undecided' respectively, but $10(12.8 \%)$ and $8(10.3 \%)$ responded that they 'disagree' and 'strongly disagree' respectively with the statement that 'the English language teachers helped the students ask for clarifications'. Likewise, in item number 8, 30(38.5), 25(32.1) and 7(8.9) of the respondents replied that they 'strongly agree', 'agree' and 'undecided', while $11(14.1 \%)$ and 5(6.4) responded that they 'disagree' and 'strongly disagree' respectively with respect to the idea that' the English language teachers encouraged the students to lower anxiety'. Similarly, in item 9,34(43.6\%), 28(35.9\%) and 5(6.4\%) of the respondents responded that they 'strongly agree', 'agree' and 'undecided' respectively, whereas 7(9\%) and 4(5.1) replied that they 'disagree' and 'strongly disagree' respectively with the statement that 'the English language teachers encouraged the students to listen to the text despite difficulties'. The above data show that most of the respondents strongly agreed (33.3\%), and agreed (28.2\%) that their English language teachers helped them to ask for clarification in listening sessions. Likewise, most of the students strongly agreed (38.5\%), and agreed (32.1\%) that their English language teachers encouraged them lower anxiety in listening classes. Similarly, most of the respondents strongly agreed (43.6\%), and agreed (35.9\%) that their English language teachers encouraged them to listen to texts despite difficulties. Likewise, $66.7 \%, 55.6 \%$ and $66.7 \%$ of the observed classroom respectively show that the above points were performed by English language teachers. So, these data depict that the English language teachers employed socio affective strategies in listening classes.

As explained earlier, items 10-14 are some benchmark questions to enquire the actual practice of English 
language teachers in terms employing sub listening skills. Accordingly, in item number 10, 2(2.6\%), 4(5.1\%) and $8(10.3 \%)$ of the respondents responded that they 'strongly agree', 'agree' and 'undecided' respectively, but $28(35.9 \%)$ and $36(46.1 \%)$ responded that they 'disagree' and 'strongly disagree' respectively with the idea that 'the English language teachers encouraged the students to predict what the text may be about'. Also, in item 11, none $(0 \%), 6(7.7 \%)$ and $10(12.8 \%)$ of the respondents replied that they 'strongly agree', 'agree' and 'undecided' respectively, while $29(37.2 \%)$ and 33(42.3\%) responded that they 'agree' and 'strongly agree' respectively with regard to the point that 'the English language teachers told the students not to worry to understand the meaning of every word they hear'. Similarly, in item number $12,10(12.8 \%), 12(15.4 \%)$ and $9(11.5 \%)$ of the respondents responded that they 'strongly agree', 'agree' and 'undecided' respectively, whereas $22(28.2 \%)$ and $25(32.1 \%)$ responded that they 'disagree' and 'strongly disagree' respectively with the idea that 'the English language teachers encouraged the students to get the main idea of the text they listen'. Likewise, in item $13,8(10.3 \%), 11(14.1 \%)$ and $6(7.7 \%)$ of the respondents replied that they 'strongly agree', 'agree' and 'undecided' respectively, but $26(33.3 \%)$ and $27(34.6 \%)$ responded they 'disagree' and 'strongly disagree' respectively with the point that 'the English language teachers helped the students get to the general understanding of the text they listen'. In the same way, in item $14,9(11.5 \%), 12(15.4 \%)$, and $13(16.7 \%)$ of the respondents responded that they 'strongly agree', 'agree' and 'undecided 'respectively, whereas $18(23.1 \%)$ and $26(33.3 \%)$ responded that they 'disagree' and 'strongly disagree' respectively with regard to the idea that 'the English language teachers made the students practice listening for specific information'.

The above data show that most of the respondents disagreed (35.9\%) and strongly disagreed $(46.1 \%)$ that their English language teachers encouraged them to predict what the text might be about before listening. Similarly, in item 11, most of the respondents disagreed (37.2\%) and strongly disagreed (42.3\%) that their English language teachers taught them that they did not have to worry to know the meaning of every word they heard in listening sessions. In item number 12 also, most of the students disagreed (28.2\%) and strongly disagreed (32.1\%) that their English language teachers encouraged them to get the main idea of the text they listened to in listening classes. Likewise, in item number 13, most of the respondents disagreed (33.3\%) and strongly disagreed (34.6\%) that their English language teachers helped them get the general understanding of the text they listened to in listening classes. In item number 14, most of the respondents disagreed (23.1\%) and strongly disagreed (33.3\%) that their English language teachers made them practice listening for specific information. Also, $77.8 \%, 100 \%, 88.9 \%, 77.8 \%$ and $88.9 \%$ of the observed classroom respectively revealed that the English language teachers did not encourage students to predict what the text might be a bout, did not help students not to worry to understand every word, failed to encourage students to get the main idea of the text, did not help students to get the general understanding of the text they listened to and did not make students practice listening for specific information. Thus, from the above data analysis one can definitely conclude that the English language teachers under consideration did not make students practice the sub listening skills using proper strategies. Classroom observation and the interview data also revel quite the same thing that they hardly teach listening skill using different strategies (perceptive strategies, cognitive strategies, metacognitive strategies) and sub listening skills in teaching listening skill. 
Table 4 .1.2: Students' responses to English language teachers' use of the three stages of listening skill. Key= $V H=$ Very highly, $H=$ Highly, $A=$ Averagely, $L=$ Lowly, $V L=$ Very lowly, $F=$ Frequency

\begin{tabular}{|c|c|c|c|c|c|c|c|c|}
\hline \multirow[t]{2}{*}{ № } & \multicolumn{8}{|l|}{ Items } \\
\hline & $\begin{array}{l}\text { In Pre listening stage, to what extent does } \\
\text { English language teacher: }\end{array}$ & your & VH & $\mathbf{H}$ & $\mathbf{A}$ & $\mathbf{L}$ & $\mathbf{V L}$ & Total \\
\hline \multirow[t]{2}{*}{1} & \multirow{2}{*}{$\begin{array}{l}\text { Introduce the topic of the text before } \\
\text { listening? }\end{array}$} & $\mathrm{F}$ & 30 & 26 & 10 & 8 & 4 & 78 \\
\hline & & $\%$ & 38.5 & 33.3 & 12.8 & 10.3 & 5.1 & 100 \\
\hline \multirow[t]{2}{*}{2} & \multirow{2}{*}{$\begin{array}{l}\text { Make you brainstorm about the topic } \\
\text { before listening? }\end{array}$} & $\mathrm{F}$ & 5 & 6 & 9 & 28 & 30 & 78 \\
\hline & & $\%$ & 6.4 & 7.7 & 11.5 & 35.9 & 38.5 & 100 \\
\hline \multirow[t]{2}{*}{3} & \multirow{2}{*}{$\begin{array}{l}\text { Ask you } 1 \text { or } 2 \text { simple questions aiming at } \\
\text { general understanding of the whole text? }\end{array}$} & $\mathrm{F}$ & 4 & 8 & 12 & 25 & 29 & 78 \\
\hline & & $\%$ & 5.1 & 10.3 & 15.4 & 32 & 37.2 & 100 \\
\hline \multirow[t]{2}{*}{4} & \multirow{2}{*}{$\begin{array}{l}\text { Tell you the purpose of listening before } \\
\text { listening? }\end{array}$} & F & 5 & 9 & 11 & 24 & 29 & 78 \\
\hline & & $\%$ & 6.4 & 11.5 & 14.1 & 30.8 & 37.2 & 100 \\
\hline \multirow[t]{2}{*}{5} & \multirow{2}{*}{ Pre-teach you some difficult words? } & $\mathrm{F}$ & 6 & 8 & 6 & 22 & 36 & 78 \\
\hline & & $\%$ & 7.7 & 10.3 & 7.7 & 28.2 & 46.1 & 100 \\
\hline \multirow[t]{3}{*}{6} & \multirow{2}{*}{$\begin{array}{l}\text { Give you clear instruction on how to do } \\
\text { listening tasks? }\end{array}$} & F & 21 & 25 & 13 & 11 & 8 & 78 \\
\hline & & $\%$ & 26.9 & 32 & 16.7 & 14.1 & 10.3 & 100 \\
\hline & \multicolumn{2}{|c|}{$\begin{array}{l}\text { In While listening stage, to what extent does your } \\
\text { English language teacher: }\end{array}$} & VH & $\mathrm{H}$ & A & $\mathrm{L}$ & VL & Total \\
\hline \multirow[t]{2}{*}{7} & \multirow{2}{*}{$\begin{array}{l}\text { Read or play text first for overall } \\
\text { comprehension? }\end{array}$} & $\mathrm{F}$ & 24 & 26 & 10 & 12 & 6 & 78 \\
\hline & & $\%$ & 30.8 & 33.3 & 12.8 & 15.4 & 7.7 & 100 \\
\hline \multirow[t]{2}{*}{8} & \multirow{2}{*}{ Read or play text again for specific details? } & $\mathrm{F}$ & 9 & 12 & 13 & 18 & 26 & 78 \\
\hline & & $\%$ & 11.5 & 15.4 & 16.7 & 23.1 & 33.3 & 100 \\
\hline \multirow[t]{2}{*}{9} & \multirow{2}{*}{ Observe your activities during listening? } & F & 38 & 29 & 8 & 3 & - & 78 \\
\hline & & $\%$ & 48.7 & 37.2 & 10.3 & 3.8 & - & 100 \\
\hline \multirow[t]{2}{*}{10} & \multirow{4}{*}{$\begin{array}{l}\text { Provide you with different listening tasks } \\
\text { like true/false, chart completion, multiple } \\
\text { choices, and completion? } \\
\text { Make you do tasks in group? }\end{array}$} & $\mathrm{F}$ & - & 2 & 20 & 26 & 30 & 78 \\
\hline & & $\%$ & - & 2.6 & 25.6 & 33.3 & 38.5 & 100 \\
\hline \multirow[t]{2}{*}{11} & & $\mathrm{~F}$ & 30 & 28 & 10 & 6 & 4 & 78 \\
\hline & & $\%$ & 38.5 & 35.9 & 12.8 & 7.7 & 5.1 & 100 \\
\hline 12 & Give different tasks to different groups? & $\mathrm{F}$ & - & 5 & 8 & 31 & 34 & 78 \\
\hline & & $\%$ & - & 6.4 & 10.3 & 39.7 & 43.6 & 100 \\
\hline & $\begin{array}{l}\text { In Post listening stage, to what extent does } \\
\text { English language teacher: }\end{array}$ & your & $\mathrm{VH}$ & $\mathrm{H}$ & A & $\mathrm{L}$ & VL & Total \\
\hline 13 & Encourage you to respond to what you & $\mathrm{F}$ & 24 & 29 & 11 & 9 & 5 & 78 \\
\hline & listen? & $\%$ & 30.8 & 37.2 & 14.1 & 11.5 & 6.4 & 100 \\
\hline 14 & Encourage you to compare your work with & $\mathrm{F}$ & - & 4 & 8 & 30 & 36 & 78 \\
\hline & your peer's? & $\%$ & - & 5.1 & 10.3 & 38.5 & 46.1 & 100 \\
\hline 15 & Encourage you to report back to the class? & $\mathrm{F}$ & - & 2 & 5 & 34 & 37 & 78 \\
\hline & & $\%$ & - & 2.6 & 6.4 & 43.6 & 47.4 & 100 \\
\hline 16 & Encourage you to write a summary of what & $\mathrm{F}$ & - & - & - & 3 & 75 & 78 \\
\hline & you listen to? & $\%$ & - & - & - & 3.8 & 96.2 & 100 \\
\hline 17 & Help you make a list of comprehension & $\mathrm{F}$ & - & - & - & 2 & 76 & 78 \\
\hline & question? & $\%$ & - & - & - & 2.6 & 97.4 & 100 \\
\hline 18 & Teach you some language items in the & $\mathrm{F}$ & 10 & 13 & 15 & 18 & 22 & 78 \\
\hline & listening text? & $\%$ & 12.8 & 16.7 & 19.2 & 23.1 & 28.2 & 100 \\
\hline 19 & Give you feedback? & $\mathrm{F}$ & 19 & 28 & 14 & 9 & 8 & 78 \\
\hline & & $\%$ & 24.4 & 35.9 & 17.9 & 11.5 & 10.3 & 100 \\
\hline
\end{tabular}


In table 4.1.2 above, items 1-6, 7-12, and 13-19 are some benchmark questions for the English language teachers' use of the pre, the while and the post listening stage, respectively. The items were given to the students to enquire the extent to which their teachers employ these stages in teaching listening skill.

Accordingly, in item number 1, 30(38.5\%), 26(33\%) and 10(12.8) of the respondents responded that their English language teachers introduce the topic of the text 'very highly', 'highly' and 'averagely' respectively, but $8(10.3 \%)$ and $4(5.1 \%)$ of the respondents responded that their English language teachers introduce the topic of the text 'lowly' and 'very lowly' respectively. In item 2, 5(6.4\%), 6(7.7) and 9(11.5\%) of the respondents replied that their English language teachers make them brainstorm ideas about the topic before listening 'very highly', 'highly' and 'averagely', whereas $28(35.9 \%)$ and $30(38.5 \%)$ of the respondents responded that their English language teachers make them brainstorm ideas about the topic before listening 'lowly' and 'very lowly' respectively. Regarding item number 3, 4(5.1\%), 8(10.3\%) and 12(15.4\%) of the respondents responded that their English language teachers ask them 1 or 2 simple questions aiming at general understanding of the whole text 'very highly', 'highly' and 'averagely' respectively, while $25(32 \%)$ and $29(37.2 \%)$ of the respondents responded that their English language teachers do so 'lowly' and 'very lowly' respectively. Likewise, in item number 4, 5(6.4\%), 9(11.5\%) and 11(14.1\%) of the respondents responded that their English language teachers tell them the purpose of the listening before listening 'very highly', 'highly' and 'averagely' respectively, but 24(30.8\%) and 29(37.2\%) of them responded that their English language teachers do so 'lowly' and 'very lowly' respectively. Similarly, in item number 5, 6(7.7\%), 8(10.3\%) and 6(7.7\%) of the respondents responded that their English language teachers pre teach some difficult words before listening 'very highly', 'highly' and 'averagely' respectively, whereas $22(28.2 \%)$ and 36(46.1\%) of them responded that their English language pre teach some difficult words before listening 'lowly' and 'very lowly' respectively. In item number 6, 21(26.9\%), 25(32\%) and 13(16.7\%) of the respondents replied that their English language teachers give clear instruction on how to do listening tasks 'very highly', 'highly' and 'averagely' respectively, but 11(14.1\%) and 8(10.3\%) of them responded that their English language teachers do so 'lowly' and 'very lowly' respectively. The analysis of the above data about the practices of pre listening stages reveals that in item number 1, most of the respondents $(38.5 \%$ and $33 \%)$ responded that their English language teachers introduced the topic of the lesson 'very highly' and 'highly' respectively. Similarly, in item number 6 , most of the respondents $(26.9 \%$ and $32 \%)$ responded that their English language teachers gave clear instructions on how to do listening tasks 'very highly' and highly. This implies that the English language teachers introduced the topic of the text and made clear instructions on how to do listening tasks as far as pre listening stages are concerned. However, according to items 2-5, the English language teachers were unable to employ the items therein. That is, in item 2, most of the respondents $(35.9 \%$ and $38.5 \%)$ responded that their English language teachers made students brainstorm about the topic before listening 'lowly' and 'very lowly' respectively. Also, in item 3, most of the respondents (32\% and 37.2\%) responded that their English language teachers asked them 1 or 2 simple questions aiming at general understanding of the whole text 'lowly' and 'very lowly' respectively. Likewise, in item number 4, most of the respondents $(30.8 \%$ and $37.2 \%)$ responded that their English language teachers told them the purpose of listening before listening 'lowly' and 'very lowly' respectively. Similarly, in item 5, most of the respondents $(28.2 \%$ and $46.1 \%)$ responded that their English language teachers pre taught them some difficult words before listening 'lowly' and 'very lowly' respectively. In the classroom observation, too, the teachers were not observed executing the above items properly except item 1 and 6 . So, the above points mean that though the English language teachers employed few of the pre listening stage which in turn, shows that the English language teachers employed the pre listening stage to a smaller extent in teaching listening skill.

As explained earlier, items 7-12 are concerned with the analysis and interpretation of English language teachers' use of the while listening stage to teach listening skill. Accordingly, in item number 7, 24(30.8\%), $26(33.3 \%)$ and $10(12.8 \%)$ of the respondents responded that their English language teachers read or play the text for overall comprehension 'very highly', 'highly' and 'on average' respectively, but $12(15.4 \%)$ and $6(7.7 \%)$ responded that their English language teachers do so 'lowly' and 'very lowly' respectively. In item number 8, $9(11.5 \%), 12(15.4 \%)$ and $13(16.7 \%)$ of the respondents responded that their English language teachers read or play the text again for specific details 'very highly', 'highly' and 'on average' respectively, while $18(23.1 \%)$ and 26(33.3\%) responded that their English language teachers do so 'lowly' and 'very lowly' respectively. In item number 9, 38(48.7\%), 29(37.2\%) and 8(10.3\%) of the respondents responded that their English language teachers observe their activities during listening 'very highly', 'highly' and 'averagely' respectively, whereas $3(3.85)$ and none $(0 \%)$ of them responded that their English language teachers observe their activities 'lowly' and 'very lowly' respectively. In item 10 , none $(0 \%), 2(2.6 \%)$ and $20(25.6 \%)$ of the respondents responded that their English language teachers provide them with different listening tasks like true/false, chart completion, multiple choices, completion et cetera 'very highly', 'highly' and 'averagely' respectively, but 26(33.3\%) and, 30(38.5\%) responded that their English language teachers do so 'lowly' and 'very lowly' respectively. In item 11, 30(38.5\%), 28(35.9\%) and $9(11.5 \%)$ of the respondents replied that their English language teachers make them do tasks in group 'very highly', 'highly' and 'on average' respectively, whereas 5(6.4\%) and 3(3.85) replied that their English language 
teachers do so 'lowly' and 'very lowly' respectively. However, in item number 12 , none $(0 \%), 5(6.4 \%)$ and $8(10.3 \%)$ of the respondents responded that their English language teachers give different tasks to different groups 'very highly', 'highly' and 'averagely' respectively, but 31(39.7\%) and 34(43.6\%) responded that their English language teachers give different tasks to different groups 'lowly' and 'very lowly' respectively. In the analysis of the above data about English language teachers' use of the while listening stage, the English language teachers were able to employ items in numbers 7,9 , and 11 , but they were unable to do so in items number 8,10 and 12 . That is, in item number, 7 most of the respondents, 24(30.8\%), 26(33.3\%) and 10(12.8\%) responded that their English language teachers read or play the text for overall comprehension 'very highly', 'highly' respectively. Also, in item number 9, most of the respondents, 38(48.7\%), 29(37.2\%) and 8(10.3\%) responded that their English language teachers observe their activities during listening sessions 'very highly', 'highly' respectively. But, in item number 8, most of the respondents, $18(23.1 \%)$ and $26(33.3 \%)$ responded that their English language teachers read or play the text again for specific details 'lowly' and 'very lowly' respectively. Similarly, in item number 10 , most of the respondents, 30(38.5\%) and 26(33.3\%) responded that their English language teachers provide them with different listening tasks like true/false, chart completion, multiple choices, completion et cetera 'lowly' and 'very lowly' respectively. Likewise, in item number 12, most of the respondents, 31(39.7\%) and 34(43.6\%) responded that their English language teachers give different tasks to different groups 'lowly' and 'very lowly' respectively. The classroom observation conducted on the teachers' use of the while listening stage also highly coincided with these data. Thus, the analysis and discussions of the above data show that even though the English language teachers employ some of the while listening stage, they could not use other important activities in this stage. This, in turn, depicts that the English language teachers used the while listening stage to some extent in teaching listening skill.

As explained previously, items 13-19 are concerned with the analysis and interpretation of English language teachers' use of the post listening stage to teach listening skill. Accordingly, in item 13, 24(30.8\%), 29(37.2\%) and $11(14.1 \%)$ of the respondents responded that their English language teachers encourage them to respond to what they listen 'very highly', 'highly' and 'averagely' respectively, while 9(11.5\%) and 5(6.4\%) responded that their English language teachers encourage them to respond to what they listen 'lowly' and 'very lowly' respectively. However, in item number 14 , none $(0 \%), 4(5.1 \%)$ and $8(10.3 \%)$ of the respondents replied that their English language teachers encourage them to compare their work with their peers' 'very highly', 'highly' and 'averagely' respectively, but $30(38.5 \%)$ and 36(46.1\%) replied that their English language teachers do so 'lowly' and 'very lowly' respectively. Likewise, in item number 15, none (0\%), 2(2.6\%) and 5(6.4\%) of the respondents responded that their English language teachers encourage them to report back to the class 'very highly', 'highly' and 'averagely' respectively, whereas $34(43.6 \%)$ and 37(47.4\%) responded that their English language teachers do so 'lowly' and 'very lowly' respectively. In item 16, none ( $0 \%)$ of the respondents responded that their English language teachers encourage students to write a summary of what they listen to 'very highly', 'highly' and 'averagely', but $3(3.8 \%)$ and $75(96.2 \%)$ of the respondents responded that their English language teachers encourage them to write a summary of what they listen to 'lowly' and 'very lowly' respectively. Similarly, in item number 17, none ( $0 \%$ ) of the respondents responded that their English language teachers help them to make a list of comprehension questions 'very highly', 'highly' and 'averagely', but 2(2.6\%) and 76(97.4\%) of the respondents responded that their English language teachers do so 'lowly' and 'very lowly' respectively. On the other hand, in item number $18,10(12.8 \%), 13(16.7 \%)$ and $15(19.2 \%)$ of the respondents replied that their English language teachers teach them some language items in the listening text 'very highly', 'highly' and 'averagely' respectively, whereas 22(28.2\%), and 18(23.1\%) replied that their English language teachers do so 'lowly' and 'very lowly' respectively. In item number 19, 19(24.4\%), 28(35.95) and 14(17.9\%) of the respondents responded that their English language teachers give them feedback 'very highly', 'highly' and 'averagely' respectively, while 9(11.5\%) and $8(10.3 \%)$ responded that their English language teachers do so 'lowly' and 'very lowly'.

In the analysis of the English language teachers' use of the post listening stage above, items number 13, and 19 were used by the English language teachers, whereas items number 14, 15, 16, 17 and 18 were not used by the English language teachers. That is, in item number 13, most of the respondents $(30.8 \%$ and $37.2 \%)$ responded that their English language teachers encourage them to respond to what they listen 'very highly' and 'highly' respectively. Likewise, in item number 19, most of the respondents (24.4\% and 35.95) responded that their English language teachers give them feedback 'very highly' and 'highly' respectively. However, in item number 14, most of the respondents, (38.5\% and 46.1\%) replied that their English language teachers encourage them to compare their work with their peers' 'lowly' and 'very lowly' respectively. Also, in item number15, most of the respondents, (43.6\% and 47.4\%) responded that their English language teachers encourage them to report back to the class 'lowly' and 'very lowly' respectively. In item number 16, almost all of the respondents (96.2\%) responded that their English language teachers encourage them to write a summary of what they listen to 'very lowly'. Similarly, in item number 17, almost all of the respondents (97.4\%) responded that their English language teachers help them to make a list of comprehension questions 'very lowly'. Likewise, in item number 18, most of the respondents, $(28.2 \%$ \& $23.1 \%)$ replied that their English language teachers teach them some language items in the listening text 
'lowly' and 'very lowly' respectively. Similarly, during the classroom observations, the English language teachers were also not seen using the above items except 'encouraging students to respond to what they listened to' and 'trying to give feedback'. So, the above data reveals that the teachers under consideration often use the while listening stage to some extent, but they employed the pre listening and the post listening stages to a very smaller extent. The analyses classroom observation and interview data also show almost similar results with the questionnaire data that the English language teachers did not employ the activities in listening stages, particularly, the pre and the post stage. This means that the English language teachers failed to employ the pre listening stage and the post listening stages to a significant effect.

Table 4.1.3: Students' Responses on English Language Teachers' Use of Right Listening Materials. Key: $S A=$ Strongly agree, $A=$ Agree, $U=$ Undecided, $D=$ Disagree, $S D=$ Strongly disagree, $F=$ Frequency

\begin{tabular}{|c|c|c|c|c|c|c|c|c|}
\hline \multirow[t]{2}{*}{ № } & \multicolumn{2}{|l|}{ Items } & \multirow[t]{2}{*}{ SA } & \multirow[t]{2}{*}{ A } & \multirow[t]{2}{*}{$\mathbf{U}$} & \multirow[t]{2}{*}{ D } & \multirow[t]{2}{*}{ SD } & \multirow[t]{2}{*}{ Total } \\
\hline & Your English language teacher: & & & & & & & \\
\hline \multirow[b]{2}{*}{1} & \multirow{2}{*}{$\begin{array}{l}\text { Designs materials to teach you listening } \\
\text { skill. }\end{array}$} & $\mathrm{F}$ & - & - & 5 & 13 & 60 & 78 \\
\hline & & $\%$ & - & - & 6.4 & 16.7 & 76.9 & 100 \\
\hline \multirow{4}{*}{$\frac{2}{3}$} & \multirow{2}{*}{$\begin{array}{l}\text { Uses authentic printed materials like } \\
\text { extracts from newspapers to teach you } \\
\text { listening skill. }\end{array}$} & $\mathrm{F}$ & - & 4 & 8 & 30 & 36 & 78 \\
\hline & & $\%$ & - & 5.1 & 10.3 & 38.5 & 46.1 & 100 \\
\hline & \multirow{2}{*}{$\begin{array}{l}\text { Uses authentic listening materials like } \\
\text { extracts from radio news to teach you } \\
\text { listening skill. }\end{array}$} & $\mathrm{F}$ & - & - & - & 3 & 75 & 78 \\
\hline & & $\%$ & - & - & - & 3.8 & 96.2 & 100 \\
\hline \multirow[t]{2}{*}{4} & \multirow{2}{*}{$\begin{array}{l}\text { Uses authentic listening materials like } \\
\text { extracts from Television or movies to } \\
\text { teach you listening. }\end{array}$} & $\mathrm{F}$ & - & - & - & 6 & 72 & 78 \\
\hline & & $\%$ & - & - & - & 7.7 & 92.3 & 100 \\
\hline \multirow[t]{2}{*}{5} & \multirow{2}{*}{$\begin{array}{l}\text { Uses authentic listening materials like } \\
\text { songs to teach you listening skill. }\end{array}$} & $\mathrm{F}$ & - & - & - & 8 & 70 & 78 \\
\hline & & $\%$ & & & & 10.3 & 89.7 & 100 \\
\hline \multirow[t]{2}{*}{6} & \multirow{2}{*}{$\begin{array}{l}\text { Uses authentic listening materials like } \\
\text { extracts from short stories to teach you } \\
\text { listening skill. }\end{array}$} & $\mathrm{F}$ & 12 & 13 & 14 & 19 & 20 & 78 \\
\hline & & $\%$ & 15.4 & 16.7 & 17.9 & 24.4 & 25.6 & 100 \\
\hline
\end{tabular}

As it can be seen from Table 4.1.3 above, some questions were distributed to the respondents to enquire their rate of agreements to the statements that ranges from 'strongly agree' to 'strongly disagree' regarding English language teachers' use of appropriate listening instructional materials.

Accordingly, in item number 1 , none $(0 \%)$ of the respondents 'strongly agree' and 'agree', and, $5(6.4 \%)$ of the respondents opted for 'undecided', while 13(16.7\%) and 60(76.9\%) responded that they 'disagree' and 'strongly disagree' respectively with regard to the idea that 'the English language teachers designed materials to teach the students listening skill'. Likewise, in item number 2 , none $(0 \%), 4(5.1 \%)$ and $8(10.3)$ of the respondents responded that they 'strongly agree', 'agree' and 'undecided' respectively, but 30(38.5\%) and 36(46.1\%) responded that they 'disagree' and 'strongly disagree' respectively with the statement that 'the English language teachers used authentic printed materials like extracts from newspapers to teach the students listening skill'. Similarly, in item number 3 , none $(0 \%)$ of the respondents responded that they 'strongly agree', 'agree' and 'undecided', whereas 3(3.8\%) and 75(96.2\%) responded that they 'disagree' and 'strongly disagree' respectively with regard to the point that 'the English language teachers used authentic listening materials like extracts from radio news to teach the students listening skill'. Also, in item number 4 , none $(0 \%)$ of the respondents responded that they 'strongly agree', 'agree' and 'undecided', but 6(7.7\%) and 72(92.3\%) responded that they 'disagree' and 'strongly disagree' respectively with the idea that 'the English language teachers used authentic listening materials like extracts from television or movies to teach the students listening skill'. In the same way, in item number 5, none $(0 \%)$ of the respondents responded that they 'strongly agree', 'agree' and 'undecided', but $8(10.3 \%)$ and $70(89.7 \%)$ responded that they 'disagree' and 'strongly disagree' respectively with regard to the statement that 'the English language teachers used authentic listening materials like songs to teach the students listening skill'. Similarly, in item number $6,12(15.4 \%), 13(16.7 \%)$ and $14(17.9 \%)$ of the respondents responded that they 'strongly agree', 'agree' and 'undecided' respectively, whereas $19(24.4 \%)$ and 20(25.6\%) responded that they 'disagree' and 'strongly disagree' respectively with the idea that 'the English language teachers used authentic listening materials like extracts from short stories to teach the students listening skill'.

From the above analysis, the following points could be drawn. That is, in item number1, most of the respondents $(16.7 \%$ and $76 \%)$ disagreed and strongly disagreed respectively that their English language teachers designed materials to teach them listening skill. Likewise, in item number 2, most of the respondents $(38.5 \%$ and 46.1\%) disagreed and strongly disagreed respectively that their English language teachers used authentic printed 
materials like newspaper to teach them listening skill. Similarly, in item number 3, almost all (96.2\%) of the respondents strongly disagreed that their English language teachers used authentic listening materials like extracts from radio news to teach them listening skill. Also, in item number 4 , almost all $(92.3 \%)$ of the respondents strongly disagreed that their English language teachers used authentic listening materials like extracts from television or movies to teach them listening skill. In item number 5, too, $10.3 \%$ of the respondents disagreed and $89.7 \%$ of them strongly disagreed that their English language teachers used authentic listening materials like songs to teach them listening skill. Similarly, in item number 6, most of the respondents $(24.4 \%$ and 25.6$)$ disagreed and strongly disagreed respectively that their English language teachers used extracts from short stories (in addition to what is in the textbook) to teach them listening skill. The classroom observations conducted to crosscheck these data also revealed that the English language teachers did not properly use appropriate materials to teach their students listening skill. In item number 7, respondents were provided with an open-ended question that deserved them to explain how their English language teachers used appropriate listening materials like extracts from newspapers, extract from radio news, extracts from television or movies, extracts from short stories and extracts from songs to teach them listening skills. Accordingly, almost all the respondents responded that they had not ever encountered such things in their listening classes. That is, they all responded that their English language teacher did not use of all the materials. According to the respondents, let alone use such materials, their English language teachers did not teach them properly the listening parts provided in their English in the text book, and complained that they told them to pass on to the other skills. Therefore, from the analysis and discussions of the above table, it could be concluded that the English language teachers did not use appropriate listening materials. By the same token the classroom observation and the interview data also show that teachers hardly use authentic instructional materials whether print or electronic materials like extracts from newspapers, radio, television or movies, songs, and short stories to teach listening skill.

\section{SUMMARY, CONCLUSIONS AND RECOMMENDATIONS 5.1 SUMMARY}

In this part, findings that were commonly found through the three tools are presented. The findings were based on the actual practice of English language teachers in teaching listening in terms of employing listening strategies: perceptive strategies, cognitive strategies, meta-cognitive strategies and socio affective strategies and sub listening skills; the extent to which English language teachers use the three stages of listening: the pre listening stage, the while listening stage and the post listening stage and English language teachers' experience of using appropriate listening materials.

With regard to perceptive strategies, analysis and the discussions of data depict that the English language teachers neither helped the students to understand speaker's use of connected speech, nor helped the students to understand key terms before listening. As far as cognitive strategy is concerned, the data show that the English language teachers failed to encourage students to relate what has been said to their prior knowledge and to help them to understand meanings that are not directly stated. The data also revealed that English language teachers did not employ meta-cognitive strategies by providing students with topic related tasks before listening and did not help students to rehearse topic related vocabulary before listening. On the other hand, the English language teachers have been found helping students to ask for clarification, encouraging students to lower anxiety and encouraging students to listen to a text despite difficulties which were used as benchmarks for socio affective strategies.

Concerning sub listening skills, the analysis and discussions of data reveal that the English language teachers: did not encourage students to predict what the text might be about; did not encourage the students to get the main idea of the text they listened to, did not help students to get the general understanding of the text they listened to, and did not make them practice listening for specific information. Regarding English language teachers' use of the three stages of listening skill, in pre listening stage, the English language teachers did not use activities like making students brainstorm before listening, asking 1 or 2 simple questions aiming at the general understanding of the whole text, telling students the purpose of listening, and pre teaching students some difficult words.

In the while listening stage, the data show that the English language teachers did not employ points like rereading or re-playing texts for specific details, providing students with different listening tasks, and giving different tasks to different groups. Regarding the post listening stage, the data depict that the English language teachers did not employ activities like encouraging students to compare their work with their peers', encouraging students to report back to the class, encouraging students to write a summary of what they listened to, helping students to make a list of comprehension question, and teaching students some language items. With respect to English language teachers' experience of using appropriate listening materials, the analysis and discussions of the data obtained depict that the English language teachers: did not design authentic listening materials, did not use authentic printed material like newspaper, did not use authentic listening materials like extracts from radio news, extracts from television or movies, extracts from songs, and extracts from short stories to teach listening skill. 


\subsection{CONCLUSIONS}

On the bases of the findings of the study, the following conclusions were drawn:

1. The English language teachers did not employ listening strategies well particularly, perceptive strategies, cognitive strategies and meta-cognitive strategies in teaching listening skill. They also failed to make student well practice sub listening skills.

2. The English language teachers employed the while listening stage to some extent, but they used the pre listening stage and the post listening stage to a smaller extent.

3. The English language teachers failed to use appropriate listening materials that are recommended in the teaching of listening.

\subsection{RECOMMENDATIONS}

Based on the findings and the conclusions drawn above, the researcher made the following recommendations:

1. English language teachers should teach listening skill using listening strategies mainly, perceptive strategies, cognitive strategies and meta-cognitive strategies. They should also employ sub listening skills in teaching listening.

2. English language teachers should use the three stages of listening skill: the pre, while and the post listening stage to a significant extent.

3. English language teachers should use appropriate listening materials either by designing or adapting or adopting instructional materials that are up to the level and interests of grade 9 students.

4. Further study needs to be conducted on Evaluation of Grade 9 English language textbook to examine its appropriateness for teaching listening skill.

\section{REFERENCES}

Andres, E. and Yasid, A. (2016). Teacher Development Program on Teaching Listening Using Virtual Resources at Public School. University of Colombia: Published MA Thesis.

Bililew Mola \& Girma Gezahegn (2015). The Role of Listening Strategy in Advancing Students' Listening Achievement and Strategy use. International Journal of Foreign Language and Research, Vol.3 (11), 13-24. Retrieved on 23/11/2018.

Black, T.R. (1999). Doing Quantitative Research. London: Sage.

Cohen, L. et. al. (2005). Research Methods in Education (5 ${ }^{\text {th }}$ ed.). London: Routledge Falmer.

Creswell, J.W. (2014). Research Design (4thed.). University of Nebraska- Lincoln: SAGE Publication, Inc. Retrieved from the Internet on 24/1/2019.

David, D. et al. (2005). Essentials of Research Design and Methodology. New Jersey: John Wiley and Sons, Inc. Gray, E. D. (2004). Doing Research in the Real World. London: Sage Publications.

Harmer, J. (1991). The Practice of English Language Teaching. New York: Longman.

Jarvis, A et al. (2018). Academic Listening Survival Strategies. A Guide for Students of English Medium University. Retrieved from internet on 20/01/2018

Mekasha Kassaye (2012). Subject Area teaching in English Language for Teachers: Module one. Addis Ababa: Addis Ababa University Press.

Miller, M. (2005). Improving Comprehension Skills in EFL, Using Authentic Materials. Sydney: University of Sydney.

Naved, Z. (2015). The Importance of the English Language in Today's World. Retrieved http://owlcation.com/humanities/importanceofenglishlanguage

Nunan, D. (1992). Research Methods in Language Learning. Cambridge: Cambridge University Press.

Wolvin, A. D. \&Coakley, C.G. (1996). Listening. London: Brown and Benchmark. 